\title{
Women's Roles, Institutions, and Social Control
}

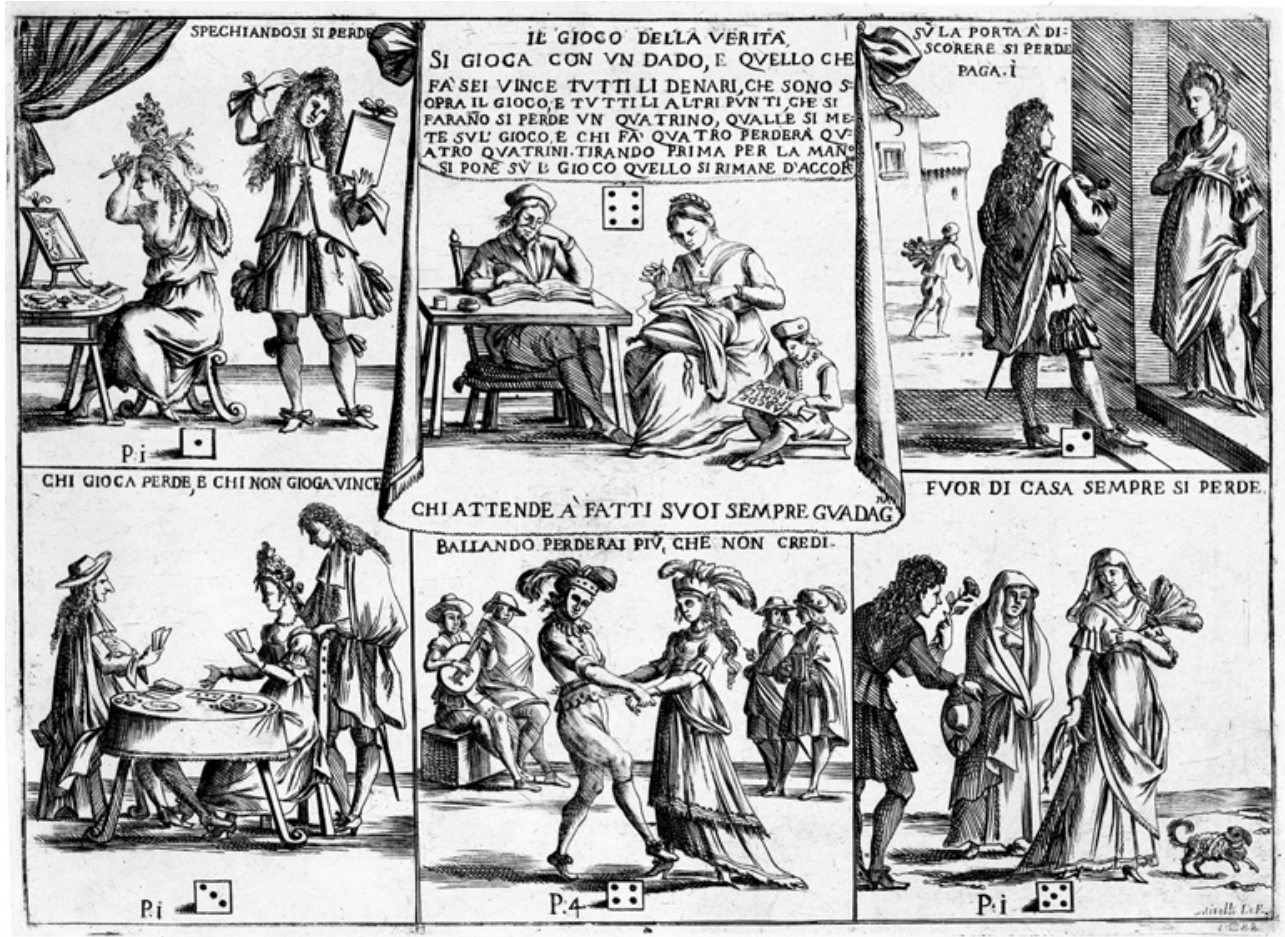

FIGURE 1 Giuseppe Maria Mitelli, Il Gioco della Verità, etching, 1688, British Museum

The figure above is taken from one of the thirty-three didactic games that Bologna-born engraver Giuseppe Maria Mitelli made between 1680 and 1712. Enjoying significant popularity in their time, these dice and board games depicted everyday places and social situations in seventeenth- and eighteenth-century Bologna - often in a humoristic way. ${ }^{1}$ Called Gioco della Verità (game of truth), this particular game was played with just one die: throwing one to five meant that the player had to pay either one or four coins and a six won the pot. With the six spaces reading captions like 'He who plays loses and he who does not play wins,' 'Dancing you will lose more than you believe' and 'Looking at oneself in the mirror, you lose,' the game provided blatant commentary on how

1 M.S. Riebe, 'Sotto i portici: Life in seventeenth-century Bologna through the games of Giuseppe Maria Mitelli (1634-1718)' (Unpublished PhD thesis, Bard College, New York, 2010). 
men and women should conduct themselves in private and public. The image for a roll of five in the right corner shows two women with a small dog being presented a flower by a man. The accompanying caption ominously reads Fuor di casa sempre si perde: outside of the house you always lose.

The notion that an honest woman's proper place was in the home was echoed by a wide range of premodern didactic and prescriptive sources such as conduct books, religious rules and commentaries. Encouraged by ideas of a Mediterranean honour culture, some scholars have taken this literature to understand women as being secluded and enclosed in either convents or strict domestic roles. ${ }^{2}$ Seen as a contrast to a freer northern Europe, ideas about 'southern' or 'Mediterranean' family systems, nuptiality, regulations concerning inheritance and dowry as well as labour participation have generally led to a pessimistic view of the position and scope of action of women in premodern Italian cities. Recent scholarship has however suggested that this generalised image misrepresents life for most of these women. ${ }^{3}$ This chapter draws on this scholarship to introduce the contours of the city of Bologna during the early modern period and, importantly, to examine women's social, economic and legal roles in it. By scrutinising both the restrictions and the opportunities for women within the spheres of the family and household, labour and urban institutions, it argues that while women acted in a patriarchal culture of constraint they nevertheless had a greater scope of action than was commonly believed.

\section{Political and Demographic Developments}

During the period under scrutiny in this book, Bologna belonged to the territories under direct sovereign rule of the Pope. In November 1506 Pope Julius II appeared at Bologna's walls accompanied by an imposing army to chase out the ruling Bentivoglio oligarchy, marking the return of papal rule over Bologna which would last until the invasion by the French in 1796. Bologna's character as a 'Republic by contract' - in which the papacy conceded significant local powers and privileges to the city in return for the acknowledgement of the papacy's overarching sovereignty - played a key role in its local political dynamics. ${ }^{4}$ From 1513 onwards, Bologna's 'mixed government' (governo misto)

2 For a discussion of the literature about cultural precepts relating to women's enclosure, see Cohen, 'To pray, to work, to hear, to speak, 291-295.

3 Ibidem, 294.

4 The term 'Republic by contract' is coined by Angela De Benedictis, see A. De Benedictis, 'Repubblica per contratto. Una città (Bologna) nello stato (Pontificio),' Scienza \& Politica 2:4 (1990) 59-72. 
was ruled cooperatively by a papal legate with greater abstract authority and a local Senate exercising greater practical power. ${ }^{5}$ The members of this Senate were drawn from the major families on either side of the factional divide (proand anti-Bentivoglio) who had previously dominated Bologna. Although these noble factions continued to wager for power with each regime change, their incorporation in the urban government established a century of relative social peace in Bologna - one that temporarily unravelled after a series of economic and natural disasters during the 1620 ond 1630 on and was gradually re-established in the half century that followed. ${ }^{6}$ During the eighteenth century a range of foreign wars wreaked havoc throughout the Italian peninsula including in the Bolognese territory, while Bologna's internal politics had sailed into comparatively calmer waters. ${ }^{7}$

Geographically a part of northern Italy (see figure 2), Bologna belonged to one of the most densely populated and urbanised regions of Europe through the medieval and Renaissance period. In around 1300, some 18 per cent of the population in northern and central Italy lived in cities with more than 10,000 inhabitants compared to only 3.5 per cent in England and Wales. ${ }^{8}$ However, while urbanisation rates grew significantly in most northern regions of Europe during subsequent centuries, those in central and northern Italy had diminished to around 13 per cent by the eighteenth century. Certain (particularly capital) cities such as Rome and Naples experienced significant growth from the fourteenth century onwards due to political centralisation, but many other towns stagnated as they diminished in importance and migrant attractiveness, due not least to the effects of the Black Death and subsequent epidemics as well as the decline of industrial and commercial activities in these towns. ${ }^{9}$

$5 \quad$ N. Terpstra, 'Republics by contract': Civil society in the Papal State,' in N.A. Eckstein and N. Terpstra (eds.), Sociability and its discontents: Civil society, social capital, and their alternatives in late medieval and early modern Europe (Turnhout: Brepols, 2009) 298.

M. Fanti, 'Bologna nell'età moderna (1506-1796),' in A. Ferri and G. Roversi (ed.), Storia di Bologna (Bologna: Bononia University Press, 2005) 212; Terpstra, 'Republics by contract,' 296-302. For an excellent analysis of the social repercussions of the breakdown of social and institutional trust in seventeenth-century Bologna, see C. Rose, A renaissance of violence. Homicide in early modern Italy (Cambridge: Cambridge University Press, 2019) 156-180.

7 Fanti, 'Bologna nell'età moderna,' 236-237.

8 And zero per cent in the Low Countries. See page 29 of the appendix to P. Malanima, L'economia italiana. Dalla crescita medieval alla crescita contemporanea (Bologna: Il Mulino, 2003).

9 M. Bosker, S. Brakman, H. Garretsen, H. de Jong and M. Schramm, "The development of cities in Italy 1300-1861,' CESifo working paper 1893 <http://www.ehs.org.uk/dotAsset/ 491c2f8o-6foe-42c2-becb-228b23ef 47b7.pdf> 3o-31; F. Giusberti and F. Roversi Monaco, 'Economy and demography,' in S.R. Blanshei (ed.), A companion to medieval and 


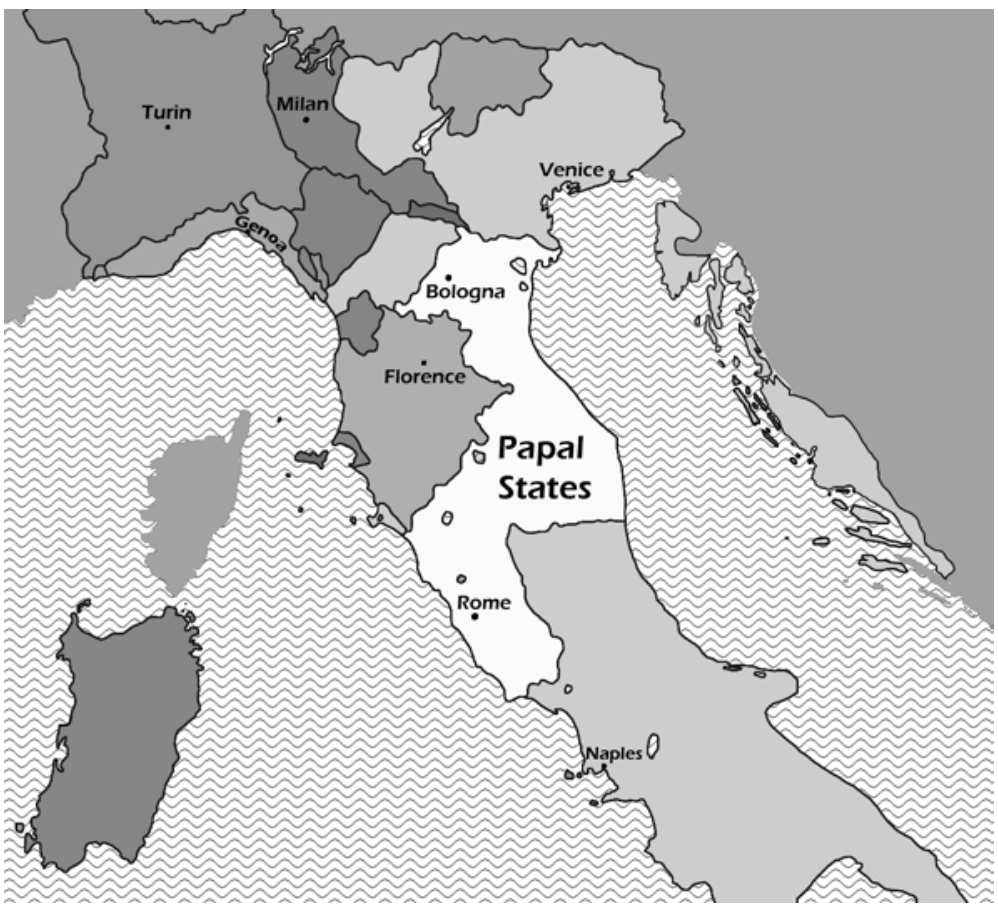

FIGURE 2 Bologna and the Papal States around 1748

MAP BY AUTHOR. BASEMAP DATA PROVIDED BY OPENSTREETMAP

Among these central and northern Italian towns, Bologna developed in a distinctive way: its urban population nearly doubled between the fourteenth and sixteenth century due to the expansion of its industrial base. Unlike other industrial towns such as Genoa, Florence and Milan, Bologna did not endure a sustained decline after the severe sixteenth-century famines, nor after the Great Plague of 1630, but instead continued to enjoy relative economic prosperity throughout the seventeenth century. ${ }^{10}$ With between 60,000 and 70,000 inhabitants in the city alone in the early modern period, Bologna was among the 15 biggest cities of early modern Europe. ${ }^{11}$ Increasing from 160,000 to 230,000 inhabitants between 1581 and 1799 , its rural population grew faster

Renaissance Bologna (Leiden: Brill, 2018) 165; C.F. Black, Early modern Italy. A social history (London: Routledge, 2001) 21; P. Malanima, 'Urbanisation and the Italian economy during the last millennium,' European review of economic history 9 (2005) 107.

10 Giusberti and Roversi Monaco, 'Economy and demography,' 165.

11 Guenzi, 'Lidentità industriale,' 46; A. Bellettini, La popolazione di Bologna dal secolo XV all'unificazione Italiana (Bologna: Zanichelli, 1961) 26-27. 


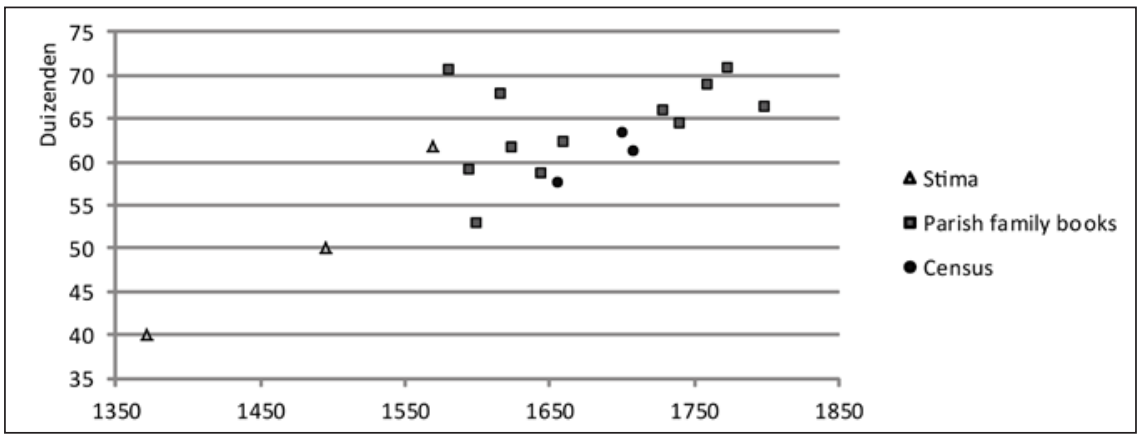

FIGURE 3 Development of the urban population in Bologna between 1371 and 1799 SOURCE: TABLES 1 AND 2 FROM BELLETTINI, LA POPOLAZIONE DI BOLOGNA, 25,48

than its urban centre did, however; a phenomenon that has also been observed elsewhere in eighteenth-century Italy. ${ }^{12}$

Women often outnumbered men in cities across the Italian peninsula. Skewed sex ratios are a well-known feature of western European urban demography in the early modern period, though they varied from place to place. ${ }^{13}$ Early modern Holland is, for example, known for its especially high surpluses; a situation that has recently been related to urban women's greater propensity to engage in crime due to their combined independence and vulnerability. ${ }^{14}$ Contrary to what some scholars have assumed based on data from Rome, an unusually 'male' city, urban sex ratios in seventeenth- and eighteenth-century Verona, Venice, Florence and Bologna adhered to the 'standard' European pattern and were all skewed towards women. ${ }^{15}$ In 1741 , for example, 53.8 per cent

12 Calculations based on the urban population as well as the entirety of the Bolognese territory, see table 2 in Bellettini, La popolazione di Bologna, 48; D. Carpanetto and G. Ricuperati, L'Italia del settecento (Rome: Laterza, 2008) 9-10.

13 K. Lynch, Individuals, families and communities in Europe 1200-1800: The urban foundations of Western society (Cambridge University Press 2003) 39.

14 Van der Heijden, Women and crime, 18-19, 120, 16o; Schmidt and Van der Heijden, 'Women alone,' 22.

Between $1600-1800$ between $5^{2}$ and 54 per cent of the Bolognese population consisted of women. For the sex ratios, see table 1.4 in Lynch, Individuals, families and communities, 40-41; Bellettini, La popolazione di Bologna, 61; E.S. Cohen, 'Open city. An introduction to gender in early modern Rome,' I Tatti studies in the Italian Renaissance 17:1 (2014) 41. For the suggestion of divergent sex ratios in northern and southern Europe (based primarily on Rome's anomalous demographic structure), see, for example, T. de Moor and J.L. van Zanden, 'Girl power: The European marriage pattern and labour markets in the North Sea 
of Bologna's urban population consisted of women. ${ }^{16}$ The persistent stereotypes of southern exceptionalism surrounding women's sheer demographic presence in these urban environments suggest that their involvement and comportment in other areas of the urban life also needs to be reconsidered.

\section{Household Structures, Property Rights and Legal Capacity}

Ideas regarding legal structures as well as marriage and property regimes have played prominent roles in the conception of premodern Italian society as a place of constraint for women. Much of what would come to represent the 'southern European model' has been based on the studies of the now wellknown Tuscan fifteenth-century catasto (cadastre). ${ }^{17}$ This iconic source revealed a society with large extended families and significant age gaps between marriage partners, and has been remembered as portraying a large patriarchal family and a "bastion of exclusive male authority."18 Aside from this assumed demographic regime, restrictions in the law provided further grounds for painting a bleak picture of seclusion and lack of autonomy for women. ${ }^{19}$ Since a woman's legal capacity was restricted to her own person, she could not hold civic office, were not entitled to a full share of the family patrimony, could not actively possess their dotal assets, and furthermore could not gain full parental authority (patria potestas) over their children..$^{20}$ Based on these pieces of evidence, it comes to no surprise that Italian women were viewed as nearly always

region in the late medieval and early modern period,' The Economic History Review 63:1 (2010) 12 .

16 See table 7 from Bellettini, La popolazione di Bologna, 61.

17 D. Herlihy and C. Klapisch-Zuber, Les Toscans et leurfamilles: Une etude du catasto florentin de 1427 (Paris: Éditions de l'École des hautes etudes en sciences sociales, 1978); KlapischZuber, C., 'State and family in a Renaissance society: The Florentine Catasto of 1427-30,' in C. Klapisch-Zuber (ed.), Women, family and ritual in Renaissance Italy (Chicago: University of Chicago Press, 1987) 1-22; P.P. Viazzo, 'What's so special about the Mediterranean? Thirty years of research on household and family in Italy, Continuity and change 18:1 (2003) 114-115.

18 Cohen, 'Evolving the history of women,' 333; Viazzo, 'What's so special about the Mediterranean?', 114-115.

19 This scholarship is reflected upon by T. Kuehn, 'Person and gender in the laws,' in J.C. Brown and R.C. Davis (eds.), Gender and society in Renaissance Italy (Longman: London/New York, 1998) 87-88; J. Sperling, 'Dowry or inheritance? Kinship, property, and women's agency in Lisbon, Venice, and Florence (1572),'Journal of early modern history 11:3 (2007) 197-204.

20 Kuehn, 'Daughters, mothers, wives and widows,' 99; Groppi, 'A matter of fact rather than principle,' 41. 
being subordinate to male authority of some sort, be it that of the father, the husband, or someone substituting for them. ${ }^{21}$

Subsequent research has criticised and nuanced this 'southern European model' in various ways. An important area of historiographical revision pertains to the social and demographic characteristics of early modern Italian towns, which cannot be reduced across the board to the multiple-generation households and a very young marriage age. Critics instead stress complex diversities up and down Italy, between urban and rural areas as well as between socioeconomic groups. ${ }^{22}$ Northern and central Italian towns such as Bologna shared important characteristics with towns in northwestern Europe such as late marriage age for both men and women; a feature that is often used to distinguish and explain the relative freedom and independence of northern women. ${ }^{23}$ In eighteenth-century Venice the average age to marry was 31.4 for men and 29.3 for women. ${ }^{24}$ Similarly, examinations of censuses and parish family books have long shown that early modern households in northern and central Italian urban centres were typically characterised by a nuclear structure. $^{25}$ Again for Venice, Daniela Hacke found that the most common household structure between 1589 and 1607 consisted of a married couple heading their own household. ${ }^{26}$ This was also the case in the city of Bologna, where a late-eighteenth-century census revealed two-thirds of the urban population living in nuclear households. ${ }^{27}$

The position of women within Italian urban environments was also less distinct than has often been suggested. Some scholars have suggested that women in southern European cities may have had less freedom of movement, not only because it was considered honourable in Italian cities to remain in the home,

$21 \quad$ Palazzi, 'Female solitude and patrilineage. Unmarried women and widows during the eighteenth and nineteenth Centuries,' Journal of Family History, 15 (1990) 445

For an excellent overview of the many contributions to this debate, see Viazzo, 'What's so special about the Mediterranean?' 111-137; S. Sovič, P. Thane and P.P. Viazzo, 'The history of European families: Old and new directions,' in S. Sovič, P. Thane and P.P. Viazzo (eds.), The history of families and households. Comparative European dimensions (Leiden: Brill, 2016) 5-7; Black, Early modern Italy, 108.

23 M. Barbagli, 'Three household formation systems in eighteenth and nineteenth-century Italy, in D.J. Kertzer and R.P Saller (eds.), The family in Italy from antiquity to the present (New Haven: Yale University Press, 1991) 254; Black, Early modern Italy, 22.

24 Black, Early modern Italy, 22.

25 M. Barbagli, Sotto lo stesso tetto. Mutamenti della famiglia in Italia dal 15. al 20. secolo (Bologna: Il Mulino, 1984) 219.

26 D. Hacke, Women, sex and marriage in early modern Venice (Aldershot 2004) 24.

27 See footnote 8 in M. Palazzi, 'Tessitrici, serve, treccole. Donne, lavoro e famiglia a Bologna nel settecento', in S. Cavaciocchi (ed.), La donna nell'economia secc. XIII-XVIII (Florence: Le Monnier, 1990) 363 . 
but also because Protestant towns had few if any of the many convents and protective enclosures that may have sequestered as many as 10 to 20 per cent of all urban Italian women. ${ }^{28}$ However, the lives of the overwhelming majority of women living outside of these enclosures resembled those of their northern counterpart in important ways. Proportions of female-headed households were comparable to those found elsewhere in Western Europe. Around onethird of late-sixteenth-century Venetian households were headed by women, between 17 and 24 per cent of the households were in early eighteenth-century Rome, an examination of Milan in 1797 recorded 16 per cent of the heads of households as female, and a study of Bologna amounted to 14 per cent. ${ }^{29} \mathrm{Fe}-$ male household heads were particularly numerous in the lower layers of the urban population. Maura Palazzi found that in Bologna in the poorer areas as many as a quarter of the families was run by a widow or an unmarried woman. ${ }^{30}$ For other regions, comparable high levels have been regarded as evidence for women's particular independence and all of the risks that came with it, including a greater likelihood of criminal behaviour. ${ }^{31}$

Scholars have also nuanced ideas about women's legal position. Importantly, they have argued that norms did not necessarily converge with practice and that women found considerable leeway to manoeuvre and mitigate the rigours of their legal subordination. ${ }^{32}$ While women did not have full parental authority over their minor children since they did not possess patria potestas, a widowed mother could gain guardianship either through the husband's testament or with the magistrates' permission. ${ }^{33}$ Another well-known example pertained to the dowry. Despite being the personal property of the bride, the ownership and management of the dowry was put under control of the groom during the marriage. Nevertheless, if women in Florence and Lucca, for

28 N. Terpstra, 'Sex and the sacred. Negotiating spatial and sensory boundaries in Renaissance Florence,' Radical history review 121 (2015) 80-82.

29 As summarized by Palazzi, 'Female solitude and patrilineage,' 453; M. D’Amelia, 'Scatole cinesi. Vedove e donne sole in una società d'ancien régime,' Memoria 18 (1986) 62-63; E. Armelloni, 'Casa, famiglia e professione nel Milano di fine '700,' Journal of the Lombard Society of history 113 (1987) 181-185; M. Chojnacka, 'Singlewomen in early modern Venice. Communities and opportunities,' in J.M. Bennett and A.M. Froide (eds.), Singlewomen in the European past 1250-180o (Philadelphia: University of Pennsylvania Press, 1999) 220.

30 Palazzi, 'Female solitude and patrilineage,' 454.

31 Van der Heijden, Women and crime, 21-22; Schmidt and Van der Heijden, 'Women alone,' 24-25.

32 D. Lombardi, 'Famiglie di antico regime,' in G. Calvi (ed.), Innesti. Donne e genere nella storia sociale (Rome: Viella, 2004) 204; Brown, 'Introduction,' 9; Kirshner, J., Marriage, dowry, and citizenship in late medieval and Renaissance Italy (Toronto: University of Toronto Press, 2015) 1-20.

Kuehn, 'Daughters, mothers, wives and widows,' 109. 
instance, perceived mismanagement of household resources, they could claim their dowries back from their husbands in court. ${ }^{34}$ The effects of other legislation are also open to interpretation. The Florentine requirement of a male guardian (mundualdus) to draw up a civil notarial act is generally seen as an extremely gendered disability in law. However, because a woman could choose any man (related or not) as her guardian, some scholars have argued that this measure may have been less restrictive than is often believed. ${ }^{35}$ Importantly, too, many other towns including Bologna, Genoa and Venice did not share these requirements, giving women more options to assume responsibilities in the legal arena. ${ }^{36}$

In general, it is important to emphasise that the roles, expectations and control of women in all of these domains depended on age, marital status and socioeconomic class. ${ }^{37}$ As a rule, women's scope of action expanded significantly in the higher age brackets, not only because of widowhood but also because it was no longer necessary for the family to control reproduction. This was also true for women from the lower social strata, where the transmission of property was less of a concern than for the propertied classes. ${ }^{38}$ Women's leeway was also highly dependent on local conditions. A French traveller to Bologna in 1691 commented on the freedoms of women with regard to other cities, writing that "the women aren't locked up like in Florence; you encounter them frequently." ${ }^{39}$ While Italian women undoubtedly acted in a culture of patriarchal constraint, it is crucial not only to consider the theoretical restrictions of their legal status but also to examine the leeway they had to act in practice.

34 C. Meek, 'Women between the law and social reality in early Renaissance Lucca,' in L. Panizza (ed.), Women in Italian Renaissance culture and society (Legenda: Oxford 200o) 187; J. Kirshner, 'Wives' claims against insolvent husbands in late medieval Italy', in J. Kirshner and S.F. Wemple (eds.), Women of the medieval world (Oxford: Blackwell, 1985) 256-303.

35 Kuehn, 'Understanding gender inequality,' 64 . For a similar argument about early modern Normandy, see Schneider, 'Women before the bench,' 24.

36 Wray, Communities in crisis, 76.

37 Kuehn, 'Daughters, mothers, wives and widows,' 98, 112, 114; Cohen, 'Evolving the history of women,' 326

38 Palazzi, 'Female Solitude and Partilineage,' 456; G. Angelozzi and C. Casanova, Donne criminali. Il genere nella storia della giustizia (Bologna: Pàtron Editore, 2014) 47

39 M. Misson, Voyage d'Italie (Amsterdam: Clousier, 1743) as cited in G. Ricci, Bologna: Storia di un'imagine (Bologna: Arte Grafiche Emiliane, 1976) 178; Riebe, 'Sotto i portici,' 59. 
Ideas about women's (declining) labour force participation have further contributed to the notion of Italian women's particularly disadvantaged position. Under-registration, underestimation and undervaluing have been common denominators for women's labour force participation all over early modern Europe, and Italy was no exception. ${ }^{40}$ More particular to southern European societies is the historiographical association of the dowry-system (i.e. the absence of a conjugal fund) with a negative effect the presence of women on the labour market; a disincentive that was reinforced by the heavy emphasis that was placed on female honour, which caused women to be ideally shielded from the work place. ${ }^{41}$

Similar to the untenability of the 'southern' household structure model, there is a growing body of work that not only criticises the notion of women's absence from the labour force in early modern Italy but instead underpins the importance of women's work in the urban economy. ${ }^{42}$ Studies have shown that middle and lower class girls themselves made significant contributions to their dowries through their own earnings and savings, illustrating that the dowry system did not necessarily exclude the development of labour-market-oriented strategies. ${ }^{43}$ Moreover, while issues of honour impacted attitudes towards certain lines of work they were outweighed by economic necessity for the largest segment of society, who could not afford to keep half of the population indoors. ${ }^{44}$

Crafts, domestic service and the retail trade were the most diffuse occupations for women in premodern European towns. Economically, the city of Bologna relied heavily on its specialised silk and hemp industry. As mandated by guild regulations, the production of textiles took place within the city walls,

40 J. Humphries and C. Sarasúa, 'Off the record. Reconstructing women's labor force participation in the European past,' Feminist economics18:4 (2012) 44-48; B. Zucca Micheletto, 'Reconsidering women's labor force participation,' rates in eighteenth-century Turin,' Feminist economics 19:4 (2013) 200-201.

41 De Moor and Van Zanden, 'Girl power,' 8. These statements are reflected upon in Zucca Micheletto, 'Reconsidering the southern Europe model,' 355; S.K. Cohn, 'Women and work in Renaissance Italy,' in J.C. Brown and R.C. Davis (eds.), Gender and society in Renaissance Italy (London and New York: Longman, 1998) 114.

Zucca Micheletto, 'Reconsidering the southern Europe model,' 367 ; Bellavitis, Il lavoro delle donne, 7-13.

43 Bellavitis, Il lavoro delle donne, 88-89.

44 Cohen, 'To pray, to work, to hear, to speak,' 289-311; Bellavitis, Il lavoro delle donne, 52; Groppi, 'A matter of fact rather than principle,' 48; O. Niccoli, Storie di ogni giorno in una città del seicento (Rome: Laterza 2000) 6o 
and the silk industry alone employed about a third of the urban population, approximately half of whom were women.$^{45}$ Contrary to popular belief, but similar to what is found in other Italian textile manufacturing towns such as Turin and Milan, women had a high share in labour force participation: it is estimated that nearly 64 per cent of Bolognese women aged eleven and over engaged in paid work, more than half of them working in the textile industry. ${ }^{46}$ Nicholas Terpstra has argued how 'silk towns,' contrary to even other types of textile industries, created an exceptional concentration of wealth in a handful of immensely wealthy merchants while thousands of poorly paid and parttime workers lived in extreme poverty. ${ }^{47}$ The silk industry in Bologna did not only generate a demand for women's relatively cheap labour, but also made their economic contributions indispensable for the survival of the household. ${ }^{48}$

Although Bologna had long stood out among the papal territories for its wealth and relatively high standards of living, the economic crisis hit the city during the eighteenth century - roughly a century later than many other textile industry towns. ${ }^{49}$ As a response to the unfolding economic crisis, the textile guilds restructured the mode of production by abandoning the rich, elaborate and expensive textiles to concentrate on the production of the simpler, lighter and cheaper textiles that were predominantly manufactured through women's domestic production. ${ }^{50}$ In the light of this restructuring, the incorporation of women into the guild system became increasingly important for the guilds' survival. ${ }^{51}$ While women had originally been excluded from the Bolognese textile guilds at their foundation in the sixteenth century, the share of female masters in the silk guild rose from 7.5 per cent in the early seventeenth century

45 Guenzi, 'Lidentità industriale,' 464-465. This was the same for Florence, see J.C. Brown and J. Goodman, 'Women and industry in Florence,' The journal of economic history 40:1 (1980) 73-80.

46 Palazzi, 'Tessitrici, serve, treccole,' 366-367; S. D’Amico, 'Shameful mother. Poverty and prostitution in seventeenth century Milan,' Journal of family history 39:1 (2005) 110; Zucca Micheletto, 'Reconsidering women's labor force participation rates,' 211.

47 N. Terpstra, 'Working the cocoon. Gendered charitable enclosures and the silk industry in early modern Europe,' in K. Kippen and L. Woods (eds.), Worth and repute. Valuing gender in late medieval and early modern Europe. Essays in honour of Barbara Todd (Toronto: Center for Reformation and Renaissance studies, 2011) 48-49.

48 Zucca Micheletto, 'Reconsidering the southern Europe model,' 368.

49 D. Dumont, 'Women and guilds in Bologna. The ambiguities of 'marginality', Radical History Review 70 (1998) 6-7.

50 Guenzi, 'Lidentità industriale,' 470; A. Guenzi, 'La tessitura femminile tra città e campagna. Bologna, secoli XVII-XVIII,' in S. Cavaciocchi (ed.), La donna nell'economia secc. XIII-XVIII (Florence: Le Monnier, 199o) 255, 257.

$5^{1} \quad$ Guenzi, 'L'identità industriale,' 470-472; Dumont, 'Women and guilds in Bologna,' 6, 17, 19. 
to a massive 83 per cent in $1796 .^{52}$ This guild membership provided women with wage regulations, some forms of assistance and a recognised juridical status, but it also introduced the economic burden of membership fees and an increase in the control over their labour, submitted them to guild jurisdiction and strict regulations regarding production without offering the chance of any real decision-making power. ${ }^{53}$ Scholars have therefore questioned whether increased guild membership was a positive development for women in the textile industry. ${ }^{54}$

According to an important Bolognese census from 1796 carried out by the cardinal Legate with the aim of organising charity relief, another 8 per cent of Bolognese women worked in commerce and trade. ${ }^{55}$ Throughout early modern Europe the rules of guilds often prevented women from becoming the official proprietors of commercial enterprises. In Bologna, one per cent of the labouring women were recorded as shopkeepers (bottegara), although it is assumed that women who operated and managed businesses on a de facto basis may have been far more numerous. ${ }^{56}$ While the official census data likely underestimated women's economic authority and autonomy, the largest proportion of women probably worked in the lower ends of trade and retail. In the census, the overwhelming majority of Bolognese women listed as performing commercial activities worked as street or market vendors. ${ }^{57}$ Among them were many mobile resellers without a fixed place or a stall on the street or market in the city, selling foodstuffs such as fruits, vegetables, grain, bread and sweets and textiles.

An interesting feature of the Bolognese case is that these commercial activities do not appear to have been open to all types of women. Firstly, the lateeighteenth-century census reveals that nearly all women with commercial occupations were born in the city of Bologna. ${ }^{58}$ The lack of migrants among those involved in retail and trade is indicative of the difficulty of accessing these occupations as immigrants and the importance of integration into the urban network. A second distinction that specifically applied to women was

$5^{2} \quad$ Guenzi, 'La tessitura femminile,' $252,255$.

53 Dumont, 'Women and guilds in Bologna,' 19; Palazzi, 'Tessitrici, serve, treccole,' 370; A. Groppi, 'Lavoro e proprietà delle donne in età moderna,' in R. Ago and A. Groppi (eds.), Il lavoro delle donne (Bari: Laterza 1996) 158. Dumont, 'Women and guilds in Bologna,' 20-21. Palazzi, 'Tessitrici, serve, treccole,' 374 .

56 M. Palazzi, 'Economic autonomy and male authority. Female merchants in modern Italy,' Journal of modern Italian studies 7:1 (2002) 20; Groppi, 'Lavoro e proprietà delle donne,' 132; Palazzi, 'Tessitrici, serve, treccole,' 374.

57 Palazzi, 'Tessitrici, serve, treccole,' 373.

$5^{8} \quad$ Ibidem, 374 . 
that commercial activities appear to have been exclusively performed by married women (two-thirds) or widows (one-third). The census data suggest that unmarried women were excluded from commerce and trade, be it in the shops or out on the streets and markets. While it seems unlikely that daughters were never expected to work in their families' shops, this exclusion was probably related to the importance attributed to women's sexual honour and the necessity of protecting it by controlling the movements of unmarried women. ${ }^{59}$

Unmarried women were actively involved in domestic service, which employed about one-fifth of the female workers in Bologna. Scholars have distinguished between a northern European and a southern model of domestic service ${ }^{60}$ In the latter model, servanthood was not a transitory life-cycle stage but a lifelong occupation for female servants as well as their male counterparts, who predominantly served in aristocratic households and made up nearly half of the servant population in early modern Italian towns like Bologna. ${ }^{61}$ Contrary to male servants who could marry and establish their own households, however, entering service for women generally entailed living within the master's household while remaining celibate. ${ }^{62}$ Another characteristic that fundamentally distinguished this occupation for men and women concerned the issue of social control. Scholars have argued that female servanthood was the object of social condemnation in early modern Italy, since working away from the protection of a male relative was regarded as endangering the girl's honour. ${ }^{63}$ Because the female servants' sexual behaviour and honour reflected on the honour of the family that employed them, it has been suggested that a significant degree of control was imposed upon them, more so than on male servants. ${ }^{64}$ For seventeenth-century Milan and Florence it has

59 Ibidem.

6o For the discussion of these models, see A. Arru, 'The distinguishing features of domestic service in Italy,' Journal of family history 15:4 (1990) 548; Zucca Micheletto, 'Reconsidering women's labor force participation rates,' 215-216; R. Sarti, 'The true servant: Self-definition of male domestics in an Italian city (Bologna, 17th-19th centuries), The history of the family 10 (2005) 421.

61 Italy is known for its comparatively high percentages of male servants compared to other European cities. See R. Sarti, 'Notes on the feminization of domestic service: Bologna as a case study (18th-19th centuries),' Acta demographica 13 (1997) 145; Sarti, 'The true servant,' 421; Arru, 'The distinguishing features of domestic service in Italy,' 549.

62 Sarti, 'The true servant,' 420; Palazzi, 'Tessitrici, serve, treccole' 372.

63 Zucca Micheletto, 'Reconsidering women's labor force participation rates,' 216, Viazzo, 'What's so special about the Mediterranean?,' 128; C. Klapisch-Zuber, 'Women servants in Florence during the fourteenth and fifteenth centuries,' in B. Hanawalt (ed.), Women and work in preindustrial Europe (Bloomington: Indiana University Press, 1986) 70-75.

64 D. Lombardi and F. Reggiani, 'Da assistita a serva. Circuiti di reclutamento delle serve attraverso le istituzioni assistenziali (Firenze-Milano, XVII-XVIII sec.), in S. Cavaciocchi 
been shown that the social control of female servants could furthermore be exerted by the various charitable institutions that sent some of the women they assisted into service for shorter or longer periods of time. ${ }^{65}$ As service in itself was seen as a risk to a woman's sexual honour, these institutions tried to safeguard it through a careful selection of the masters they sent women to, but also by threatening women with the loss of the dowry they could otherwise claim from the charitable institution in case of sexual transgression, and legal action against the deflowerer.

While concerns for women's sexual honour permeated many 'regular' occupations, prostitution was not illegal in Italy. Protestant countries as well as France and Spain had prohibited prostitution by the early seventeenth century, Italian civic governments primarily treated prostitutes as fee- and fine-paying workers in the civic economy. ${ }^{6}$ In Bologna, the only consistently enforced legislation was the annual registration with the Ufficio delle Bollette (the Office of Receipts) and the regular purchase of licences. ${ }^{67}$ The 0.5 to 1.8 per cent of the urban female population that were registered at the Bollette most likely represented the more established, long-term prostitutes. ${ }^{68}$ Many others are believed to have resisted registration because they did not view themselves as prostitutes, but rather regarded their extramarital sexual activity merely as a step towards marriage, only used their sexuality as a resource occasionally or temporarily, or had only one or few steady partners. ${ }^{69}$ While studies on Florence have pointed to an increasing repression and even criminalisation after the middle of the seventeenth century, there is significant evidence that both local authorities and residents were until that time relatively tolerant of prostitutes and prostitution..$^{70}$ Recent scholarship has demonstrated that Bolognese and Roman prostitutes were incorporated into local city neighbourhoods and

(ed.), La donna nell'economia secc. XIII-XVIII (Florence: Le Monnier, 1990) 301-302; Arru, 'The distinguishing features of domestic service in Italy,' 556 .

65 Lombardi and Reggiani, 'Circuiti di reclutamento delle serve,' 301-319.

66 D'Amico, 'Shameful mother,' 111; V.G. McCarthy, 'Prostitution, community and civic regulation in early modern Bologna' (PhD thesis, University of Toronto, 2015) 12.

67 McCarthy, 'Prostitution, community and civic regulation,' 12, 212.

68 Compare the total number of registered prostitutes in table 3.2 in McCarthy, 'Prostitution, community and civic regulation,' 149 and the female population according to Bellettini, La popolazione di Bologna, 61.

69 McCarthy, 'Prostitution, community and civic regulation,' 238-240; T. Storey, Carnal commerce in Counter-Reformation Rome (Cambridge: Cambridge University Press, 2008) 119122; D'Amico, 'Shameful mother,' 109-120; L. Ferrante, 'La sessualità come risorsa. Donne davanti al foro arcivescovile di Bologna (sec. XVII),' Mélanges de l'École française de Rome 99:2 (1987) 989-1016.

70 J.K. Brackett, 'The Florentine Onestà and the control of prostitution, 1403-168o,' The sixteenth century journal 24:2 (1993) 298-299. 
communities and were 'seen and known' rather than shunned and segregated. ${ }^{71}$ They were furthermore integrated into the network of care that unfolded during this period. In addition to special convents for ex-prostitutes, dubbed the Convertite, shelters for fallen women were erected in many cities in Italy so that they could be socially cleansed and reinserted into society. ${ }^{72}$

\section{$4 \quad$ Interlocking Systems of Assistance and Control}

As the concerns about women in the urban economy already indicated, anxieties regarding women's unrestricted sexuality affected not only those affiliated with prostitution but essentially all women in early modern Italy. ${ }^{73}$ From the late fifteenth century onwards the poor were increasingly seen as a danger to society, especially the uncontrolled women among them who could use their sexuality as a resource and thereby constituted a liability to the family economy. ${ }^{74}$ Centuries before the well-known custodial institutions in Victorian England, integrated networks of semi-public charitable institutions emerged all over Italy from the sixteenth century onwards, seeking to correct, supervise and help 'problematic' women and girls. ${ }^{75}$ This system consisted not only of orphanages, workhouses, prisons and conservatories, but also of dowry investment funds, institutions for mutual assistance and, importantly, a variety of enclosed shelters for women at the fringes of society. These institutions, which were also established in other parts of Catholic Europe, essentially aimed to guide women towards matrimony: it helped them save money for their dowry, helped battered women survive their bad marriages, and helped the widowed to remarry. ${ }^{76}$

An important feature of these institutions is that they provided an extensive network linking shorter and long-term care and control throughout women's different life stages. Nicholas Terpstra's sample of women who entered

$71 \quad$ McCarthy, 'Prostitution, community and civic regulation,' 210-211, 270; E.S. Cohen, 'Seen and known. Prostitutes in the cityscape of late-sixteenth-century Rome,' Renaissance studies 12:3 (1998) 394

72 Terpstra, Cultures of charity, 212, 215.

73 Ibidem, 17.

74 Brackett, 'The Florentine Onestà,' 274; Terpstra, Cultures of charity, 59; L. Ferrante, 'Malmaritate tra assistenza e punizione (Bologna secc. XVI-XVII),' in Forme e soggetti dell'intervento assistenziale in una città di antico regime: Atti del IV colloquio (Bologna, 20-21 gennaio, 1984) (Bologna: Istituto per la storia di Bologna, 1986) 107; D’Amico, "Shameful mother,' 110 .

75 Cohen, The evolution of women's asylums, $3,8$.

76 Terpstra, Cultures of charity, 17; Ferrante, 'Malmaritate tra assistenza e punizione,' 93. 
Bologna's Casa del Soccorso di S. Paolo - a sort of halfway house and reformatory for adulterous wives, concubines and prostitutes - is revealing in this regard: at least three of the fourteen women he studied subsequently went to other custodial homes to become servants, and two other women entered a convent. ${ }^{77}$ Indeed, in the course of the seventeenth and eighteenth centuries, some Italian cities like Bologna are believed to have developed into an "interlocking and coordinated municipal system, with girls and women moving between institutions according to requirements of protection, instruction, correction or space." ${ }^{78}$

Especially the lay shelters and refuges for women at the fringes of society had an increasingly purgative edge to them that made charity, discipline and enclosure synonymous from the seventeenth century onwards. ${ }^{79}$ Although many charitable institutions set out to provide assistance to vulnerable women, they were not necessarily always admitted voluntarily. The Pia Casa delle Malmaritate, established in Bologna in 1563 for 'unhappily married women' took in women seeking voluntary refuge from their often violent marriages, but also housed 'difficult women' who could be admitted by their husbands or male kin for years on end. ${ }^{80}$ Older institutions such as the Ospedale degli Esposti, a foundling home for illegitimate children, also became more punitive towards the mothers that abandoned them. Initially instated as a measure to save the lives of children while allowing women to retain their good reputation, the Esposti began charging a 25 lire fee to abandon a child, one-sixth of an artisan's average annual wage..$^{81}$ If this sum could not be paid, as was the case for many poor working families, the mother had to move into a special dormitory to work as an unpaid wet nurse for a year. It has been argued that the costs of feeding and sheltering these young imprisoned mothers rendered the measure economically counterproductive, suggesting that it was less about

77 Out of the 24 entrants examined, the immediate futures of 14 women were known: 1 was murdered, 8 were expelled 3 were sent to custodial homes and 2 became nuns. See Terpstra, Cultures of charity, 214-215.

78 S. Woolf, The poor in Western Europe in the eighteenth and nineteenth centuries (London/ New York: Methuen, 1986) 25.

79 Terpstra, Cultures of charity, 200, 215.

8o Cohen, The evolution of women's asylums, 141; M. Cavina, Nozze di sangue. Storia della violenza coniugale (Rome: Laterza, 2011) 49-51; Ferrante, 'Malmaritate tra assistenza e punizione,' 84-88.

81 Lombardi, 'Marriage in Italy,' in S. Seidel Menchi (ed.), Marriage in Europe, 1400-1800 (Toronto: University of Toronto Press, 2016) 111; A. Bianchi, "L'elemosina di un bambino": Pratica e controllo dell'abbandono all'ospedale dei bastardini (secc. XVI-XVIII),' Sanità, scienza e storia 2 (1989) 44. 
economic logic than about disincentive and discipline. ${ }^{82}$ This dual nature of assistance and control characterised many of the charitable institutions for women in early modern Italy.

Although the constellation of Italian custodial institutions did not principally target women with a criminal inclination, there was a link with deviance and punishment that has not sufficiently been explored in the literature. Alongside the women who entered the convents, workhouses and refuges on their own initiative, an unknown number of them were placed there by family members or magistrates for punitive enclosures. ${ }^{83}$ In Victorian England, roughly a quarter of the women who appeared before the court on some criminal charge were sent to a custodial home by a magistrate without ever being convicted.$^{84}$ For early modern Italy, we lack such information about the procedures and acts that caused women to be placed in the early modern Italian enclosures. Nevertheless, criminal women were sometimes confined in custodial institutions. According to Sharon Cohen, former prostitutes, rape victims, rebellious girls, abused wives, displaced widows and "women who had committed a crime" were all brought together in these 'custodial warehouses' for troublesome, marginalized women..$^{85}$

Lay confraternities, civic rulers and church leaders all cooperated in this system of care and control. ${ }^{86}$ The example of illegitimate pregnancies is perhaps most illustrative for the interconnectedness of the various charitable, ecclesiastical and secular criminal institutions of control. In an attempt to prevent infanticide, Bologna's 1613 criminal bylaws added to the local bailiffs' tasks the responsibility for keeping an eye on unmarried pregnant women until they relinquished the new-born to the Esposti foundling home. ${ }^{87}$ From 1645 onwards, another ordinance furthermore obliged midwives to denounce 'irregular pregnancies' to the Tribunale del Torrone. In practice, however, these events were by no means solely a concern for the secular criminal authorities. When pre- or extramarital pregnancies came to light, local officials - contrary to the rules - most likely dealt with them informally. ${ }^{88}$ Rather than denouncing them formally to the criminal court, they were first brought to the attention of the

\footnotetext{
82 Terpstra, Cultures of charity, 250-251.

83 Cohen, The evolution of women's asylums, 17, 36, 79; Terpstra, Cultures of charity, 213; Cavina, Nozze di sangue, 48.

84 Zedner, Women, crime and custody, 288.

85 Cohen, The evolution of women's asylums, 36, 45, 63 .

86 Black, Early modern Italy, 204; D. Lombardi, 'Famiglie di antico regime,' in G. Calvi (ed.), Innesti. Donne e genere nella storia sociale (Rome: Viella, 2004) 206-207.

87 Angelozzi and Casanova, Donne criminali, 109-110.

88 Ibidem, 110-111.
} 
religious authorities and the ecclesiastical court in order to assess whether a marriage could be arranged. If this effort proved unsuccessful, the pregnancy was reported to the guardian of the foundling home, where the mother (or her midwife) was expected to leave the child upon birth. ${ }^{89}$ Only as a last resort did notices of illegitimate pregnancies reach the criminal court, revealing the many interconnected institutions of control that came before it.

The web of institutional control for early modern Italian women was vast, connecting neighbourhood communities, and civic and charitable institutions as well as the ecclesiastical and secular authorities. ${ }^{90}$ This institutional intrusion - seeking above all to preserve and restore the honour of women and their families - not only constituted repression but also offered opportunities to women, in the very least in the sense of a safety net. It was furthermore not uncommon for women or their kin to bring cases before courts themselves. Especially when they were pregnant, women stood fairly good chances before either the ecclesiastical court to appeal to the binding nature of a marriage promise, or before the secular criminal court to file a suit for a non-violent rape, hoping to negotiate either a marriage arrangement or to be dowered. ${ }^{91}$ When these types of cases came before the court during the early modern period, women themselves were rarely on the receiving end of punishment. ${ }^{92}$ While these legal options for deflowered women deteriorated in the eighteenth century, the system of care and control on the Italian peninsula was still rather extensive compared to other regions in Europe, affecting the lives of a wide range of 'problematic women.' 93

89 Bianchi, "'L'elemosina di un bambino," 42-43; Bianchi, 'Madri e padri davanti al Tribunale arcivescovile,' 42.

9o Lombardi, 'Marriage in Italy,' 111.

91 G. Arrivo, Seduzioni, promesse, matrimoni. Il processo per stupro nella Toscana del settecento (Rome: Edizioni di storia e letteratura, 2006) 202; Lombardi, 'Marriage in Italy' 105; N. Terpstra, 'Real and virtual families. Forms and dynamics of fostering and adoption in Bologna's early modern hospitals,' Mélanges de l'École française de Rome - Italie et Méditerannée modernes et contemporaines 124-1 (2012), DOI: 10.4000/mefrim.266, 5 .

92 Arrivo, 'Sposarsi in tribunale. Sessualità e matrimonio nella Toscana del settecento,' Storicamente 6 (2010), DOI: 10.147/stor84 (accessible via <http://dx.doi.org/10.1473/stor 84>) 2; Ferrante, 'La sessualità come risorsa,' 1013; G. Ruggiero, The boundaries of Eros. Sex crime and sexuality in Renaissance Venice (New York: Oxford University Press, 1985)42.

93 Ferraro, Nefarious crimes, contested justice. Illicit sex and infanticide in the Republic of Venice, 1557-1789 (Baltimore: The Johns Hopkins University Press, 2008) 7; Bianchi, 'Madri e padre davanti al Tribunale arcivescovile,' 63; Arrivo, Seduzioni, promesse, matrimoni, 20; S. Cavallo and S. Cerutti, 'Female honor and the social control of reproduction in Piedmont between 1600 and 180o,' in E. Muir and G. Ruggiero (eds.), Sex and gender in historical perspective (Baltimore: Johns Hopkins University Press, 1990) 100; L. Sandri, 'Matrimoni mancati. "Pericolate" e "gravide occulte" dell'ospizio di Orbatello di Firenze nel XVIII e XIX secolo,' in M. Lanzinger and R. Sarti (eds.), Nubili e celibi. Tra scelta e costrizione (secoli $X V I-X X)$ (Florence: Udine, 2006) 73; Lombardi, 'Marriage in Italy,' 107. 


\section{5} Conclusion: Agency within a Culture of Constraint

The aim of this chapter was to examine the social, economic and legal position and roles of women in the urban fabric of early modern Bologna. Based on secondary literature, it sought to re-examine older notions regarding a dichotomy between northern and southern European societies in which ideas about supposed southern family systems, nuptiality, regulations concerning inheritance and dowry, and labour participation have led to a pessimistic view of the position of women. These works indicate the potential hazards of extrapolating actual practices from law codes or prescriptive literature alone, and suggest that a simple contrast between a free north and a restrictive southern Europe does not do justice to the social complexities and dynamics of either region.

A persistent scholarly presumption is that a range of structural contours of life on the Italian peninsula was uniquely disadvantageous to women vis-à-vis other European contexts. Italian women were denied active possession of their dotal assets, did not have an equal share in their fathers' patrimonies and furthermore had significantly limited capacity to own and transmit property. Yet the extent to which these legal restrictions effectively curtailed women's agency in these fields has been subject to debate. Not only has the direct link between the dowry system and women's presumed passiveness been dispelled, scholars working on Italy have also located female agency in women's circumvention of their limited legal rights through the manipulation of legal resources. The extensive network of interlinking charitable and civic institutions that enclosed up to one-fifth of the urban female population is also viewed as playing an ambiguous role. Aside from the strategies for lineage preservation strategies of patrician women, these convents, shelters and workhouses functioned as a means for controlling and disciplining women, but simultaneously provided marginal women with a safety net outside of the family structure.

Italian towns possessed many of the characteristics generally attributed to the freer northern Europe. The city had, for example, a prevalence of nuclear families, a comparable share of female-headed households, and proportions of women active in the urban labour markets that were comparable to or even higher than those observed in northern Europe. The historiographical examination of the legal, social and economic structures has thus indicated that stereotypes of radical passivity and seclusion do not capture the complex realities of most Italian women's lives. Since they attest to the discrepancy between norms and practice by their very nature, this book will employ criminal court records to probe women's ability to display agency in their licit and illicit conduct while navigating this culture of constraint. 